\title{
Ideology in public comments towards news about Jakarta election in social media
}

\author{
Liza Halimatul Humairah ${ }^{1}$, Agustina ${ }^{2}$, Ngusman Abdul Manaf ${ }^{3}$ \\ ${ }^{123}$ Universitas Negeri Padang, Padang - Indonesia, (liza.halimatulhumairah@yahoo.com)
}

\begin{abstract}
The 2017 of Jakarta Election is not only enlivened by the comments of politicians and experts, but also followed by the general public in a critical, obscene, and massive way. This study aimed to reveal the ideology in public opinions about the discourse of Jakarta election at social media. This research used qualitative-descriptive approach with content analysis method, and based on the critical discourse analysis theory by Norman Fairclough. The result of the research showed (1) about $57.4 \%$ of public opinions represent ideology of Islamic religion by raising the issue of the importance of Aqeedah, Sharia, and morals for leaders, through vocabularies like the similar faith, fellow moeslems, humane, and dirt, (2) a number of $34.8 \%$ show the ideology of secularism with the issue of electing the government leaders not a religious leader through the use of vocabularies such as performance, don't, clean, not corrupt; while (3) just $7.8 \%$ represent the ideology of liberalism with the issue such as no offense for the public to choose their leader through the use of vocabularies such as freedom, logical thinking, realistic, and common sense.
\end{abstract}

Keywords: ideology, public comments, discourse of election

\section{Introduction}

To study public comment on the discourse of election news is important because the election of head of state and head of region cannot be separated from society as its subject (Usfinifit, Suprojo, and Setyawan, 2014). Every time before the regional election, political conversations are scattered in social media (Budiyono, 2016). The society's comments will never be separated from the particular ideology that underlies behinds their thought (Abdunasir, 2015, Ramanathan \& Hoon, 2016; Widyawari \& Zulaeha, 2016). To reveal the hidden thought or ideology of a particular discourse from a linguistics basis, it is done through critical discourse analysis (Vahid, 2012; Bukhari \& Xiaoyang, 2013; Asghar, 2014; and Ali \& Nordin, 2016).

Research on critical discourse analysis about social media has been done by many previous researchers, some of which are Rahimi \& Riasati (2011) and Ahmadi \& Asl (2013) in Iran, Ahmed (2014) in Pakistan, Sideeg (2015) in Australia, Faris \& Paramasivam (2016) in Mandela, Ramanathan \& Hoon (2016) in Malaysia, and Mohammadi (2017) in Iran. In general, the results of the study show that critical discourse analysis can reveal the hidden and ideology brought by the media and journalists in a discourse. 
Based on these studies, it is known that a lot of previous research that examines the ideology in a particular discourse, but more dominantly reveals the ideology of journalists and media that covers it. Similar studies that examine ideology in public commentary on a political news discourse on social media are still rare. In this capacity, this research is indispensable in the realm of language learning as a renewal of research in the study of critical discourse analysis, with the aim to answer the research question: (1) what ideologies are exist in public comment about the discourse of Jakarta Election news in social media based on the use of vocabulary? and (2) What strategies used by the public in his comments on the discourse of Jakarta Election news in social media?

\section{Method}

This research applied qualitative-descriptive approach with content analysis method, and also based on the critical discourse analysis theory by Norman Fairclough in three dimensions, namely: (1) text analysis, (2) discourse practice analysis, and (3) socio-cultural practice analysis (Fairclough, 2003). This Fairclough approach has been used by former researchers to reveal ideology, as has been done by Asghar (2014); Ali, Christopher \& Nordin (2016); and Mohammadi and Javadi (2017). However in this study, the ideology in public comments on the Jakarta Election only presented in one dimension, particularly, the text dimension.

The data of this study were words, phrases, and sentences also clusters of sentences containing certain ideological representations in public comment on the discourse of Jakarta 2017 Election which is sourced on social media, Facebook which is located under the online news portal column. Therefore, the main instrument in this study was the researchers equipped with tools in the form of computer media to download the data, inventory format sheets, and sheets of classification formats for data collection. Furthermore, for data analysis, method of analysis according to Miles and Huberman (1992) is used in three stages, particularly (1) data reduction, (2) data presentation, and (3) drawing conclusions in accordance with the step procedure of each stage.

\section{Results and Discussion}

\section{Results}

Based on the data analysis, 151 public comments (data) were found on the discourse of Jakarta Election news in social media which contains a certain ideological representation in terms of vocabulary choice, as shown in the following table.

Tabel 1. Ideology in Societies' Comments towards News about Jakarta Election in Social Media

\begin{tabular}{|c|l|l|c|}
\hline No & Aspects & \multicolumn{1}{|c|}{ Findings } & Percentages \\
\hline 1. & Ideology & $\begin{array}{l}\text { 1. Religionism } \\
\text { a. Aquedah } \\
\text { b. (Ibadah dan Muamalah) } \\
\text { Sharia } \\
\text { c. Behaviour }\end{array}$ & $57,4 \%$ \\
\cline { 3 - 4 } & Secularism & \\
\cline { 3 - 4 } & Liberalism & $34,8 \%$ \\
\cline { 3 - 4 } & Total & $7,8 \%$ \\
\hline 2 & Strategy & 1. Active structure & $54,7 \%$ \\
\cline { 3 - 4 } & 2. Passive structure & $45,2 \%$ \\
\cline { 3 - 4 } & & Total & $\mathbf{1 0 0} \%$ \\
\hline
\end{tabular}


Expression of religionism uses a passive structure around $66 \%$ and active structure $33 \%$; Expression of secularism uses a passive structure about $61,5 \%$ and active structure $38,5 \%$; Expression of religionism uses a passive structure nearly $98 \%$ and active structure only $2 \%$;

Based on the data classification, it can be seen that overall there are three types of viewpoints or ideologies existed in the society of Jakarta in commenting on election news on social media, specifically ideologies that are distinguished on the basis of religious relations with the system of government, namely religionism (87 data), secularism (55 data) and liberalism (9 data).

\section{Religionism}

The kind of vocabulary that represents the ideology of religion/religionism in public comment is a lexeme associated with Islamic terms, such as praying, moeslem, mosque, similar faith, kaffir, dirt, and so on. Public comments that represent religionism in terms of the use of vocabulary can be divided into three categories, namely (1) aqeedah, (2) sharia, and (3) morals.

Public comments that represent religionism in the category of aqeedah can be seen in the following data.

(1) Who considers themselves as Muslims, do not choose Ahok, choose (leader of) the same faith(RK: 05/01/17).

"Yang merasa orang muslim jangan memilih Ahok, pilihlah yang seiman (RK: 05/01/17)."

(2) For all citizens of Jakarta, please do not choose Ahok because he is a kaffir (non-moeslem) (IB: 20/01/17).

"Buat seluruh warga Jakarta tolong jangan pilih Ahok karena dia kafir (IB: 20/01/17)."

In the commentary session, the public selects and uses the vocabulary of moeslem, similar faith, and kaffir in order to discredit the actor. RK and IB wrote the comment wanted to inform the moeslem's readers that do not choose Ahok because he shares not same faith with Moeslems or in the other words, he is kaffir. According to Islam's view on choosing leaders, the ummah shall elect a leader in faith so that it is forbidden to choose non-Muslims leader. It indicates that both RK and BI are Moslems and relate religious matters to the government affairs.

Public comments that represent religionism in the category of sharia can be divided in two categories namely (a) worship, (b) muamalat

Public comments in the category of sharia, with subcategories of worship, can be seen in the following utterances.

(3) Oh Allah, ,", make Mr. Anies and Mr. Sandi as governor and the representative, make them a trustworthy leader ,",', Aamiin YRA (WS: 16/04/17).

“Ya Allah, ,", jadikan Pak Anies dan Pak Sandi gub/wakil gub DKI Jkt, jadikan beliau pemimpin yang amanah, ,", Aamiin YRA (WS:16/04/17)."

(4) Bismillah ya Allah ... May the results of a temporary survey .... until the election day ... and deliver Mr. Anis and Mr. Sandi to be elected as governor .... we pray for you from afar ... (IS: 16/04/17).

“Bismillah ya Allah...Semoga hasil survey sementara....sampai dgn hari pencoblosan...dan mengantar kan bpk Anis Bpk Sandi sampai menjadi gubernur terpilih ....dari jauh kami mendoakan... (IS:16/04/17)."

The above comment is a prayer or hope from WS and IS in the hope that Anies-Sandi candidates pair will be elected as governor of DKI Jakarta. It is marked by a choice of vocabulary ... Ya Allah and Bismillah ya Allah ... with the hope that the Anies-Sandi would be a trustworthy leader. Both comments are one of the supportive voices for Anies -Sandi duet.

Public comment in the category of sharia, with subcategories of muamalat, can be seen in the following utterances

(5) I am dwie ,,$\prime \prime$, we as fellow Muslims can only remind our Muslim brothers and sisters, all back to each of them, all submit to God, at least we have delivered the mandate of Allah according to the 


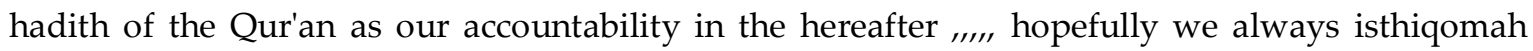
(SS: 07/02/17).

"sya dwie, ,',!', kita sebagai sesama muslim hanya bisa mengingatkan saudara2 kita yang sesama muslim,semua kembali ke mereka masing2 semua serahkan Kepada Allah,setidaknya kita sudah menyampaikan amanah Allah sesuai hadist Al-Quran sebagai pertanggungjawaban kita di

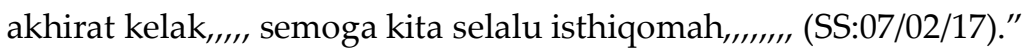

The comment was written by the SS with the intent to remind Muslim's audiences to choose leaders of the same faith (Islam) as conveyed in the Qur'an characterized by vocabularies such as Muslims, the trust of Allah, the hadith, and the Qur'an. The comment is a form of concern from a Moeslem as a member of Islamic society to fellow Muslims and also as a form of support to the AnisSandi pair. On the contrary, this is also a manifestation of dislike from the speaker to the Ahok-Djarot couple because Ahok is not a Muslim (kaffir).

Public comment which represents the religionism, with subcategories of akhlak (behavior), can be seen in the following utterances

(6) The dirt of Ahok's supporter. when people are worshiping, they are dancing dangdut. From there, it can be concluded which people are good \& bad (BI: 05/01/17).

"Kotoran pendukung ahok. Orang pada sholat, pendukung ahok malah joget dangdutan. Dari situ dapat disimpulkan mana orang baik \& buruk (BI:05/01/17)."

Disgusting and unholy. This utterance indicates that BI does not like Ahok's supporters because Ahok's supporters are something disgusting. Then, BI also uses the vocabulary "sholat" (prayer) in the comments ... at the time of the people at the prayer, Ahok's supporters do dancing Dangdut ... Ahok's supporters are referred to as dirt for dancing at the time Muslims pray. It shows that Ahok's supporters are people who are shameless because they do not appreciate Muslims in worship.

\section{Secularism}

The vocabulary that represents secularism in public comment is vocabularies that are not related to particular religion (Islam) and the speaker tends to use in the word in prohibition form, like in the following utterances:

(7) Never make any religion as a mask to achieve the intention of being ruler ," because it will bring you into an arrogant, greedy, and it makes you arrogant and irrational (DRA: 07/02/17).

"Jgn pernah jadikan agama apapun buat topeng utk mencapai niat jdi penguasa,,krn membawamu menjadi manusia arogansi, serakah, dan menjadikanmu lupa daratan, kehilangan akal (DRA: 07/02/17)."

(8) Agree if religious affairs do nothing with politics and election. whoever wins and loses we remain one, Indonesia (GA: 15/02/17).

"Setuju kalau politik, pilkada jangan bawa2 agama. siapa yg menang dan kalah tetaplah kita satu Indonesia (GA: 15/02/17)."

In the comment, DRA uses word choice religion and mask also the phrase do not involve religious affairs, addressed to the people who carry religion into governance affair. Religion here is only considered a mask. It means, religion as a means or a way to envelop political interests especially, wining the gubernatorial elections. DRA and GA as members of community indirectly invite the people of Jakarta not to mix religious matters into systems related to government. This is because Jakarta does not choose religious leaders but chooses government leaders.

\section{Liberalism}

The vocabularies that represent liberalism in public comments can be seen in the following quotations.

(9) My suggestion,,, let our citizens freely choose according to their conscience ..... !!! There is no more intimidation and promises of heaven which that ended with nonsense ..... !!!! (DRA: 07/02/17). 
“saran gue,,,biarlah warga negara kita bebas memilih sesuai hati nurani.....!!! Jgn ada intimidasi dan janji2 surga yg berujung ZONKKKK.....!!!! (DRA: 07/02/17)."

(10) I'm not a citizen of Jakarta, but according to me Anis is just a clever in theorizing. However, Mr. Basuki, a figure who does not want TO BLAME, every PROTESTED, he's looking for a scapegoat. It's not a leader"s attitude. I was not impressed with the both (I: 13/04/17).

"Gue bukan warga Jakarta, tpi menurut gue pak anis tu Cuma pandai teori aja. Kalo pak basuki orgnya gak mau DISALAHKAN setiap DIKOMPLAIN dia mencari kambing htam. It bkn skap seorang pemimpin. Gue nggak srek sm dua2nya (I:13/04/17)."

In the comments above, there is a word 'free' which according to Indonesian Dictionary (2008: 154) means 'completely off' (unimpeded, disturbed, etc. so that it can move, speak, do, etc.). So, if it is associated with the ideology of liberalism in the commentary, the word 'free' indicates to the reader that everyone is free to move, speak, act or conduct in accordance with his/her own wishes, including in terms of choosing leaders of Jakarta (Governor). So, certain parties do not need to propagandize, evenmore to force people in choosing one of the candidates under certain excuses, including nonvoting as expressed in the above data.

\section{Strategy used in Public comments}

Based on the results of data analysis, there are two strategies that people use when commenting about the election news of Jakarta i.e (1) strategy of active structure (activize), (2) strategy of passive structure (passivize)

\section{Active structure}

Public comments using strategy of active structure can be seen in the complete quote in the following data.

(11) Choose a candidate of Jakarta governor who does not insult and ridicule the contents of scripture from another religion (such as wi-fi ALMAIDAH password kafir) in order to create harmony among people of different religions so as to create a peaceful atmosphere in society (EA: 13/04/17).

"Pilih cagub dki yg tidak menghina mengolok2 isi petunjuk kitab sucinya dari umat Agama lain (seperti ucapan wi-fi ALMAIDAH password kafir) supaya tercipta kerukunan antar umat yg berbeda agama sehingga tercipta suasana rukun tenang dlm masyarakat (EA:13/04/17)."

(12) There is a floating house, then a flying motor, now there is a house with $0 \%$ down payment, it was all dreams, brothers. WHAT A LIE for the sake of a position (RID: 09/04/17).

"Ada rumah apung, sekarang ada ojek terbang, ada rumah dp 0\%, semuanya mimpi om. Sampai segitunya MEMBOHONGI publik demi seonggok jabatan (RID:09/04/17)"

Coments that represent religionism which offends aqeedah affair delivered using an active structure strategy that is marked with a verb select a candidate governor who is not insulting and mocking a religion; it is similar with the data (12), do not choose Ahok, and deceive the public for the sake of a position. With the use of such strategies, the reader will know who is the actual agent of the event and what the agent does to the patient or Object in the text so it is very sensitive to affect the reader's paradigm.

\section{Passive structure}

Public comments using strategy of passive structure can be seen in the complete quote in the following data.

(13) Mother, have you all heard the preach from Mr. Djarot? He is just smiling while Koran is blasphemed by Ahok.

"tuh ibu2 denger ceramah Djarot? Lah alquran dilecehin ahok aja dia cengar-cengir (JM:15/03/17)." 
(14) Why they do not campaign in middle-class Jakarta residents? Because they know, they will be laughed and abandoned (RP: 29/01/17).

"Kenapa mereka tidak berkampanye di wilayah warga Jakarta menengah ke atas? Karena mereka tahu mereka akan ditertawakan dan ditinggalkan (RP:29/01/17)"

Comment that represents religionism concerning aqidah affair is delivered by using passive structure. The use of such a passive strategy, influenced JM as a member of society when commenting with the structure The Qur'an, the Muslim holy book is blasphemed, where the word 'Qur'an' is highlighted in the text and placed at the beginning of the sentence. Thus, the speaker can lead other people's opinions as the reader of the comment as quick as possible for action committed by particular actor (Ahok) towards the Qur'an. Similarly, RP uses passive strategy '(being) laughed' and '(being) abandoned' which explains if campaigning in a middle-class resident area of Jakarta. The strategy of passive structure also happens in the data (12) e.g. 'not to be blamed' and 'to be complained.'

Based on the results of the data analysis, three ideological representations were found in public comments on the election news of Jakarta 2017 Election from the aspect of word choice and use of vocabulary, namely (1) religionism, (2) secularism, and (3) liberalism. First, the representation of religionism is the most commonly found (57.4\%) in public comments, especially the ideology of Islamic religion which alludes to the affairs such as aqeedah, sharia, and morals. This is very possible because one of the candidates for governor (Ahok) at that time stumbled upon the famous SARA case with the jargon "Penistaan Agama" (religious blasphemy). The situation is what causes many comments from the public which links Jakarta Election with a religious affair. Additionally, the text of public comments is written in a speech society that the majority are adherents of Islam. So, many people participated and issued their aspirations about Jakarta Election through comments on social media Facebook (Budiyono, 2016). This fact is in accordance with the opinion of Usfinifit, Suprojo, and Setyawan (2014) that every regional election can not be separated from the people who will vote for it.

Secondly, the next type of ideology that dominates in public commentary is the secular ideology/secularism $(34.8 \%)$. Secularism is a notion that separates religion from the system of government (Hurd, 2004, Tiwary, 2017). Based on the results of several studies in other countries, there are many people who do not mix religious issues into matters relating to leadership (Altwajri, 1997; Abdulsyani, 2012; Susanto, 2013). For a secular society, religion has nothing to do with choosing leaders, what matters is the program and its performance. The vocabulary that represents the ideology of secularism in public commentary on the news discourse in the Jakarta Election is vocabulary that calls for support to Ahok and vocabulary expressing dislike to Anies-Sandi pair.

Third, another ideology which is contained in the public comment in the news discourse of Jakarta election is a liberal ideology/liberalism (7.8\%). The liberal society aspires to a free society which is characterized by freedom of thought for every individual. Liberalism rejects restrictions, especially by government and religious dogma (Suryono, 2009; Zarkasyi, 2011). In this study, liberal ideology is characterized by a comment that states no concern with propaganda and forceful message which occurs in the community to favor one of the candidates. For liberals, choosing a regional head is a freedom for the people and must conform to their conscience.

From the strategy of comment expression, the three ideologies are presented through two strategies, namely: (1) strategy of active structure; by way of writing a comment by mentioning the actor or social groups in the news with the intention to marginalize that social actors and that groups; (2) strategy of passive structure, by writing a comment without mentioning the actor or social group in their comments with a view to protecting that social actors.

The findings of this study are relevant to the results of other studies conducted by some of the previous researchers. First, "ideology in a discourse can be expressed through the study of critical discourse analysis" (Abdunasir, 2015; Shahsavar, 2015; Faris \& Paramasivam, 2016; and Ramanathan 
\& Tan Bee Hoon, 2016). Second, "there is an implicit ideology behind the language use" (Asghar, 2014; Shahsvar \& Naderi, 2015; Widyawari \& Zulaeha, 2016; Faghih \& Moghiti, 2017). Thirdly, therefore "the use of language will never be apart from the ideology that lies behind the minds of its users" (Fairclough, 2003). Furthermore, these findings suggest that "ideology will affect a person in action"; this is relevant to the findings of Syam (2010).

\section{Conclusions}

There are three types of ideology in public comment on the news discourse at Jakarta Election 2017 in social media, namely (1) Religionism with the issue of the importance of aqeedah, sharia, and morals for a leader, demonstrated through the vocabularies such as similar faith, moeslem, humane, dirt, unholy. (2) Secularism with an emphasis on the issue of choosing government leaders rather than religious leaders, manifested through vocabularies such as performance, real proofs, clean, not corruption and others. (3) Liberalism with an emphasis on the issue of no compulsion for people to choose leaders, indicated through vocabularies such as freedom, logical thinking, realistic, common sense and the likes.

The three ideologies are delivered by using two strategies, particularly (1) active structure with the aim to highlight the actors and the object of the event (actor) so that the effect presented is more open, more rational, and more sensitive. This strategy is more dominantly used in the expression of ideology of religion/religionism and liberal ideology/liberalism; and (2) a passive structure with the aim of emphasizing the acts with the object being performed by hiding the performer of the events (actor), which is more primarily used in the expression of secular ideology.

Thus, ideology in a discourse can be expressed through the study of critical discourse analysis. In fact, the use of language will never be separated from the ideology that lies behind the thoughts and desires of its users. Therefore, there is always an implicit ideology behind the language use.

\section{Acknowledgments}

Author would like to thank Prof. Dr. Agustina, M.Hum as advisor I and Dr. Ngusman, M.Hum as a advisor II patiently and willingly have given their time, input and guidance to the author in completing this research. Thank you author say to the parents who always pray author in completing this research. Furthermore, author say thank you to friends also gave inputs to the completion of this research.

\section{References}

Abdulsyani. (2012). Sosiologi skematika, teori dan terapan. Jakarta: PT Bumi Aksara.

Ahmadi, H dan Asi, E. S. (2013). Editorials and ideologies. International Journal of Culture Sains dan Olahraga, 1 (4).

Ali, M. K \& Nordin, M. Z. F. (2016). Linguistic legitimation of political events in newspaper discourse Advances in Language and Literary Studies, 7 (4).

Altwajri, A.O. (1997). Islam, barat, dan kebebasan akademis. Yogyakarta: Titian Ilahi Press.

Asghar, J. (2014). Language power and ideology in commercial discourse: A prologue to critical dicourse analysis for neophyte analysts. Academic Journal of Interdisciplinary Studies, 3 (4).

Asghar, J. (2014). Words speak louder than actions: a critical analysis of ideological perspectives in media discourse. International Journal of Humanities and Social Science, 4 (5).

Budiyono. (2016). Media sosial dan komunikasi politik: media sosial sebagai komunikasi politik menjelang pilkada dki jakarta 2017. (Jurnal Komunikasi). 11 (1). 
Bukhari, N. H.S dan Xiaoyang, W. (2013). Critical discourse analysis and educational research. Journal of Research \& Method in Education (IOSR-JRME), 3 (1).

Dianastiti, F. E. dan Mardikantoro, H. B. (2016). Analisis wacana kritis pemberitaan harian suara merdeka, harian republika, harian kompas, dan tabloid derap guru dalam pembentukan citra guru. Jurnal Pendidikan Bahasa dan Sastra Indonesia Seloka 5 (2).

Faghih, E \& Moghiti, R (2017). Persian renderings of english conceptual discourse patterns: a case study of animal farm. International Journal of Comparative Literature \& Translation. Volume 5 (3).

Fairclough, N. (2003). Language and power relasi bahasa, kekuasaan, dan ideologi. Malang: Boyan Publishing.

Faris, A.A dan Paramasivam, S. (2016). Ideologies in mandela's no easy walk to freedom. International Journal of Applied Linguistics \& English Literature, 5 (5).

Hurd, E. S. (2204). The political authority of secularism in international relations. European Journal of International Relation, 10 (2).

Miles, M.B dan Huberman, A.M. (1992). Analisis data kualitatif. Terj. Tjetjep Rohendi Rohidi. Jakarta: University Indonesia Perss.

Mohammadi, M dan Javadi, J. (2017). A critical discourse analysis of donald trump's language usein us presidential campaign, 2016. International Journal of Applied Linguistics \& English Literature, 6 (5).

Rahimi, F dan Riasati, M.J. (2011). Critical discourse analysis: scrutinizing ideologically-driven discourse. International journal of Humanities and Social Science, 1 (16).

Ramanathan, R dan Hoon, T.B. (2016). Application of critical discourse analysis in media discourse studies. The Southeast Asian Journal of English Language Studies, 21 (2).

Sideeg, A. I. A. (2015). Traces of ideology in translating the qurān into english: a critical discourse analysis of six cases across twenty versions. International Journal of Applied Linguistics \& English Literature, 4 (5).

Shahsavar, Z. \& Naderi, M. S. H (2015). Investigating the influence of ideology on translation: a critical discourse analysis of "ATale of Two Cities" and its Persian Translations. International Journal of English Language Translation Studies. Published on: 07/03/2015.

Sugiyono. (2010). Metode penelitian pendidikan. Bandung: Alfabeta.

Suryono, Y. (2009). Politik ideologi pendidikan. Yogyakarta: LaksBang Mediatama.

Susanto, A. (2013). Filsafat ilmu suatu kajian dalam dimensi ontologis, epistimologis, dan aksiologis. Jakarta: Bumi Aksara.

Syam, F. (2010). Pemikiran politik barat: Sejarah, filsafat, ideologi, dan pengaruhnya tehadap dunia ke-3. Jakarta: PT Bumi Aksara.

Usfinit, Y, Suprojo, A, \& Setyawan, D. (2014). Perspektif partisipasi politik masyarakat pada pemilihan kepala daerah (pilkada) kota Malang. Jurnal Ilmu Sosial dan Ilmu Politik,3 (1).

Vahid, H. (2012). The power behind images: advertisement discourse in focus. International Journal of Linguistics, 4 (4).

Widyawari, C. P. G dan Zulaeha, I. (2016). Representasi ideologi dalam tuturan santun para pejabat negara pada talk show mata najwa. Jurnal Pendidikan Bahasa dan Sastra Indonesia Seloka 5 (1).

Zarkasyi, H. F. (2011). Liberalisasi pemikiran islam: gerakan bersama missionaris, orientalis, dan kolonialis. Jurnal Tsaqafah, 5 (1). 